\title{
The Dwarf Mistletoe, A Plant Parasite
}

M. V. S. Raju and T. A. Steeves

(University of Saskatchewan, Saskatoon)

The genus Arceuthobium, commonly known as dwarf-mistletoe, belongs to the family Loranthaceae and comprises about 12 species which are mainly distributed in the northern hemisphere. It is a common parasitic plant on pine, spruce and fir and has been known to cause considerable damage to them.

During a recent visit to La Ronge (in northern Saskatchewan) we had an opportunity to see an area of jackpine forest about 20 miles south on La Ronge-highway. We were amazed by the abnormal appearance of many of the plants. The abnormalties were such that they are commonly referred to as "witches' broom." In many vascular plants "witches' broom," or the bushiness of the lateral branches, is attributed to infection by a fungus or a virus. However, in the present case, we were able to find Arceuthobium americanum Nutt.,"* growing on both young and old plants of jackpine, causing certain morphological deformaties which make the hostwood useless. Some of the plants

*The species has tentatively been identified as Arceuthobium americanum Nutt.

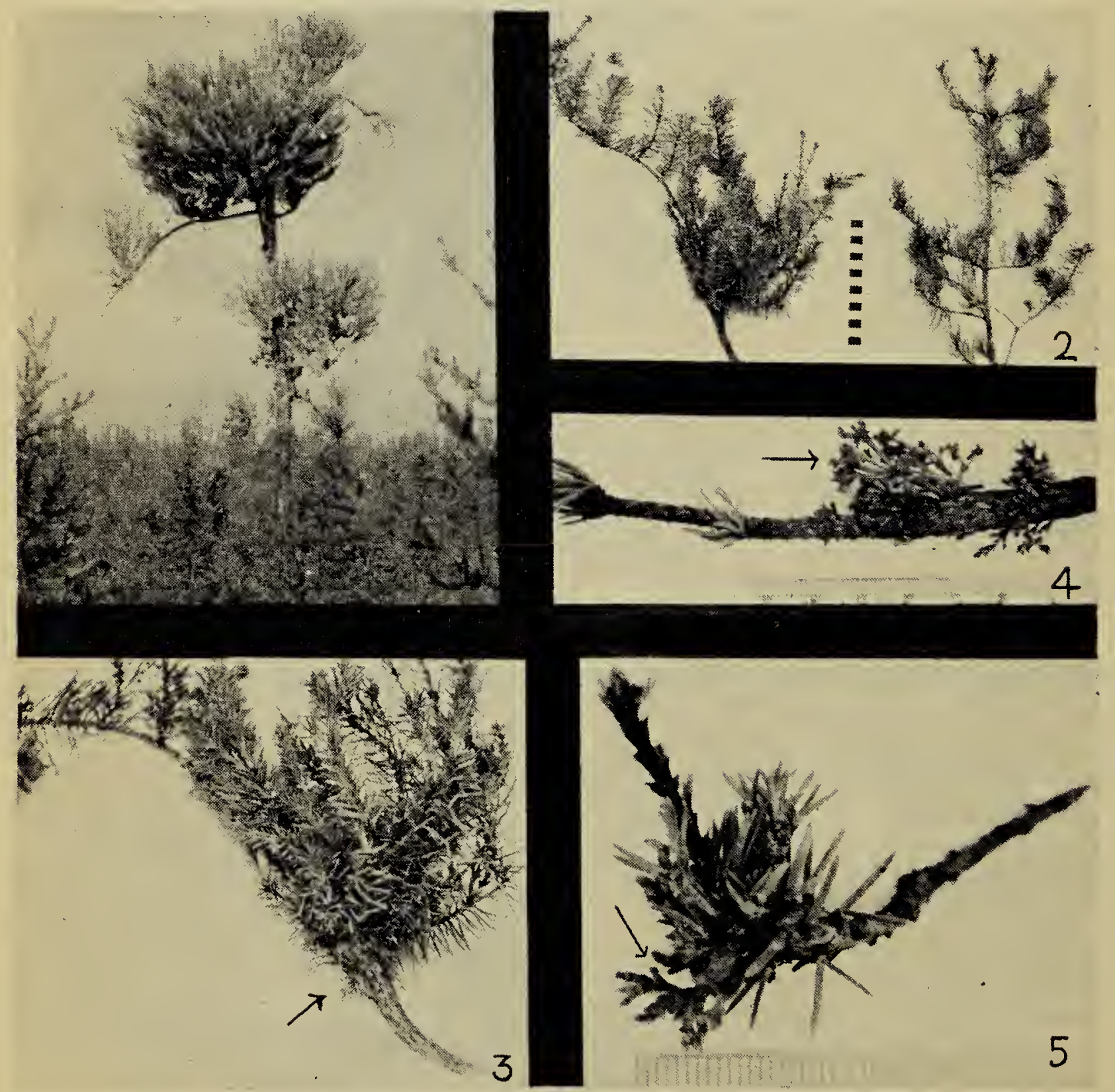

Explanation of Figures. 1. Jack pine with brooming induced by dwarf mistletoe. 2. Infected and normal shoots of jack pine. 3. Enlarged view of broom, arrow points to parasite. 4. Enlarged view of the parasite on a branch of its host. 5. A jack pine branch showing "knot" caused by the dwarf mistletoe. 


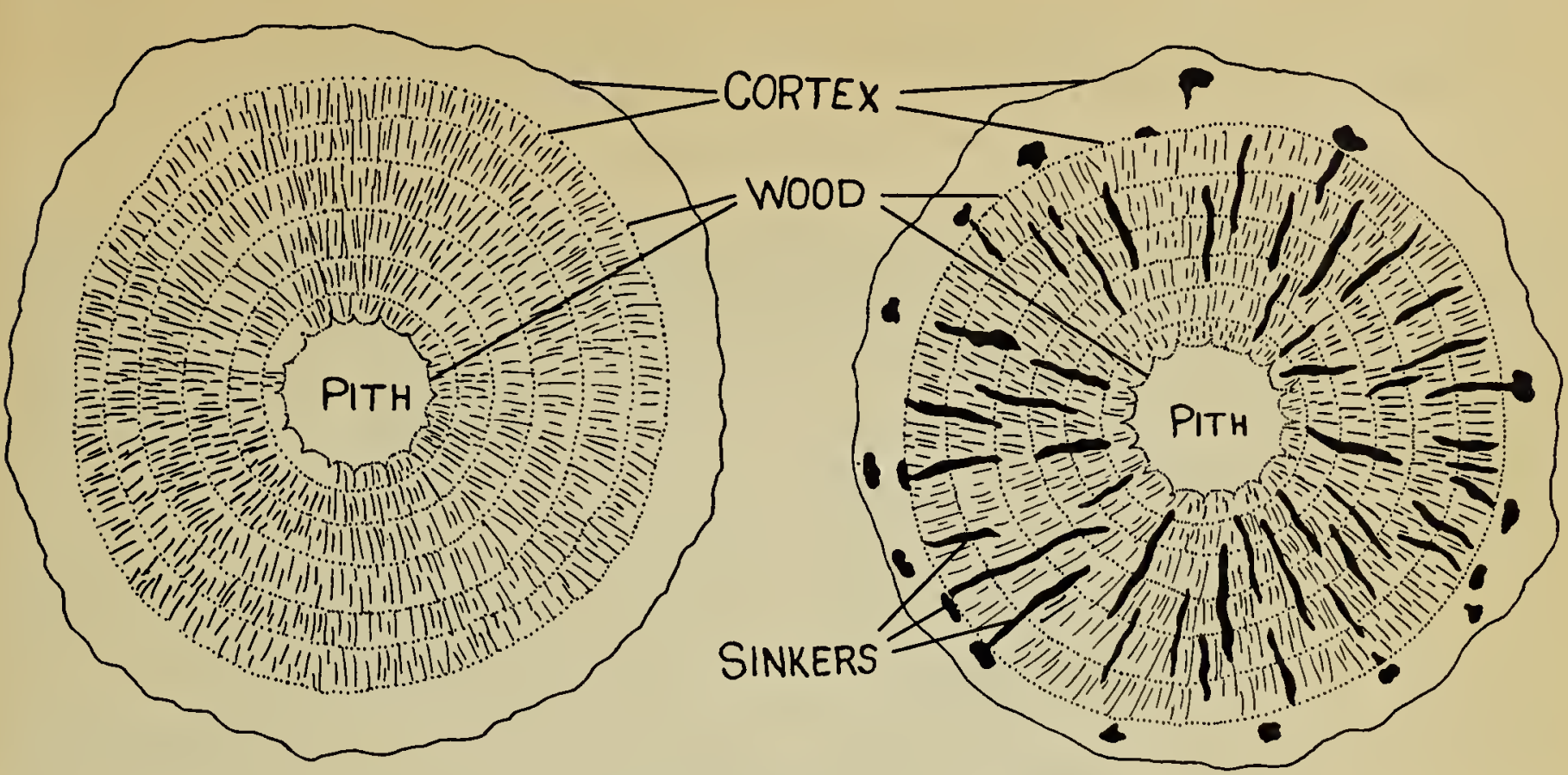

Fig. 6. Diagrams showing normal (left) and infected wood. Note the sinkers in the infected wood.

looked dwarfed or had a very stunted growth.

Arceuthobium americanum has aerial shoots which vary in height from 4 to 50 millimeters. The entire plant can be divided into two portions - the lower part which is inside the host plant, and the aerial portion. The aerial or exposed portion has articulated shoots, the branches of which have opposite scaly leaves. In the axils of these scaly leaves develop flowers. The flowers are small, one to three millimeters in diameter. The female flowers produce fruits which are sticky and are disseminated by wind, small mammals or birds.

The portion of the parasite within the host plant is often called the "endophytic system," and its morphology has been a subject of considerable controversy. It forms a highly ramifying system of strands, which are found both in the cortex and in the wood of the host. Such strands have been termed "sinkers," some of which penetrate radially into the solid wood of the host and irregularly separate it.

A glance at the published literature indicates a casual mention of a peculiar type of vegetative propagation in the "endophytic system" of the parasite. The "sinkers" in the cortex are capable of extensive ramification producing profuse endophytic branches some of which penetrate radically into the host-wood. They also produce buds which develop into aerial flower-bearing shoots. The mechanism concerning the initiation and de- velopment of buds is not fully understood. Although not much attention has been given to this mode of "vegetative propagation," it seems that it is of major biological importance in many parts of Canada.

Arceuthobium is a very important plant economically. It is extensively found in the coniferous forests of U.S.A. and Canada. The dwarfmistletoe brings about morphological and anatomical abnormalities such as swellings, cankers, etc., which ultimately may become sites of insect invasion. This can result in necrosis of the infected regions and finally in the rotting of wood. The parasite also induces the excessive formation of parenchyma and the development of abnormal grain, which lower the quality of the host-wood. Moreover, it decreases both the growth and the longevity of the host plant, and in some adult plants the parasite induces such contortions that the wood has little timber value. For further details referencès listed at the end of this article may be consulted.

Much time and effort have been expended in eradicating the infection and controlling the spread of the dwarf-misţletoe. Various herbicides have been used and some biological and sylvicultural methods have been applied. None of these methods, however, has proved completely successful. In this connection, it may be suggested that attempts should be made to develop a clear understanding of the growth and development of

(Continued on page 84 ) 


\section{FIRST REPORT OF SEA LAVENDER IN SASK.}

by Dorothy R. and

Douglas E. Wade, Regina

On August 7, 1960, we stopped at an abandoned house which represents the entire town of Big Muddy, south of the Big Muddy Valley. Later we learned from a local rancher that the house once served as headquarters for the R.C.M.P. Exploring the hills and coulees in the vicinity of the town we came across a picturesque cemetery located on a hillside high above the valley floor. Prominent among those buried here were the Marshall family, who came into the valley in 1895 .

The cemetery was fenced and did not show the signs of heavy grazing which were evident in the surrounding grasslands. Through the cemetery and along the fence there was an unusual plant which reminded me of statice, the cultivated plant which is often used in dried form in floral arrangements.

Parts of the plant were pressed and it has been tentatively identified by Dr. George Ledingham, University of Saskatchewan, Regina Campus, as sea lavender, Limonium sp. Gray's Manual of Botany, 1950, mentions only two species for eastern North America and the genus Limonium, is not mentioned in floras of Manitoba, Alberta, or North Dakota. Limonium, of the family Plumbaginaceae, is made up of about 180 species, mostly perennial herbs, well scattered about the world but mainly growing on sea coasts in the northern hemisphere, especially in Asia. The Standard Cyclopedia of Horticulture, by L. H. Bailey, 1935, lists 32 species which may be cultivated.

Since this genus, Limonium, has apparently not been reported previously as being established in any of the prairie provinces or adjoining states it is interesting to think of this plant thriving in an abandoned cemetery which apparently has not been visited for many years.

It is interesting to speculate about how this plant came to this lonely ranch country. Was it first grown in a nearby garden and then deliberately seeded or planted in the cemetery?

\section{COMMON MULLEIN IN SASKATCHEWAN IN 1956}

by Mrs. MacGillivray, Moose Jaw

John Hudson's description of the Common Mullein, Verbascum thapsus L., in the March 1962 Blue Jay sounded very familiar and I looked through my pressed plants to get the details.

On July 31, 1956, I found a single plant along the Canadian National Railway track, near my home. Since I had not seen the plant previously in Saskatchewan I pressed leaves and flowers which I identified as Common Mullein. I have now sent this specimen to Dr. George Ledingham, University of Saskatchewan, Regina Campus, and he has verified the identification and deposited the specimen in the herbarium there.

It is interesting to note that this Moose Jaw specimen was not in the large waste railway area in the center of Moose Jaw but along the high dry bank of the C.N.R. where it skirts the northern fringe of the city. It will be interesting to see if this plant can become established and act as a weed in Saskatchewan.

\section{(Continued from page 83 )}

the parasite on the host plant. A thorough knowledge of the life-history of the parasite and its relationship with the host plant will probably give some clue. which can be exploited to control the spread of this pernicious parasite and conserve the natural wealth of our coniferous forests.

We are grateful to Mr. Norman Ferrier for assistance with photographic work.

\section{REFERENCES}

Kuijt, Job. 1955. Dwarf Mistletoes. Bot. Rev., 21:569-619.

1960. Morphological aspects of parasitism in the dwart mistletoe (Arceuthobium)., Univ. California Publ. Bot. 30:337-436.

Srivastava, L. M. and Esau, K. 1961. Relation of dwart mistletoe (Arceuthobium) to the xylem tissue of conifers. II. Effect of the parasite on the xylem anatomy of the host. Amer. J. Bot., 48:209-215.

Thoday. D. and Johnson, E. T. 1930. On Arceuthobium pusillum Peck. I. The Endophytic system. Ann. Bot., 44:393-413. 